\title{
An Empirical Analysis of Financial Reforms in Pakistan: Does it Affect Economic Growth?
}

\author{
Waliur Rehman, Goher Fatima, and Waqar Ahmad
}

\begin{abstract}
Banks indulge in catering the needs of government, public sector organization and private businesses. Government of Pakistan introduced several financial reforms for the improvement of banking sector. State Bank of Pakistan (SBP) has taken many influential steps in order to increase performance of the banking sector in Pakistan. This study aimed to enlist the major financial reforms undertaken by the Government of Pakistan and explore their impact on economic growth of Pakistan; furthermore it has explored correlation among economic growth, deposits, lending, real interest rate, savings, and inflation, taking data of thirty six years (19732008). Regression analysis using E-Views was applied and explored a positive impact of financial reforms on economic growth. It is recommended to remove the interest rate ceiling and overcome the problem of inflation.
\end{abstract}

Index Terms-Financial Sector Reforms, Economic Growth, Inflation, Real interest Rate

\section{INTRODUCTION}

Banks indulge in catering the needs of government, public sector organization and private businesses. Government of Pakistan introduced several reforms for the improvement of banking sector. Fewer lending to small and medium enterprises was given before the reforms. Medium enterprises generated most of development and employment in the country. State Bank of Pakistan (SBP) has taken many influential steps in order to increase performance of banks in Pakistan. Economic development of a country can be ensured either by optimally utilizing the available resources or revamp the procedures to employ already available resources. The banking sector plays a vital role in the developmental activities, as they offer financial resources to the public and private sector for achieving the developmental goals. Before the reforms there was no balanced structure in banks. In mid 1980s public sector banks were dominating the financial sector. At that time foreign banks were more in numbers than state owned but they were not in direct competition with state-owned. Government allowed local private banks to operate and privatize national banks in 1990s. Main aim of these reforms was to restructure banking sector and make banks compatible. Non performing loans were the main concern of the banking industries, as they failed to recover these loans.

Manuscriptt received July 26, 2011; revised August 3, 2011.

Waliur Rehman is with the Institute of Engineering and Management Sciences (FUIEMS)(wrehman88@gmail.com)

Goher Fatima is with the Department of Economics, Foundation University College of Liberal Arts and Sciences, (FUCLAS)(goher.economist@gmail.com)

Waqar Ahmad,Prospect Research Scholar-Graduated from BU, Islamabad (2010)
This inability of the banks damaged the lending capacity and their overall efficiency; the technological advancement has contributed a lot in the revolutionary changes in the banking industry of Pakistan [5].

Reforms were introduced in a number of different dimensions; privatization of public financial institutions, removal of restrictions to entry into banking, measures aimed at spurring competition in financial markets, reduction of legal reserve requirements, elimination of directed lending, prudential regulation measures, measures aimed at securities markets development and openness of capital account etc along with interest rate liberalization. Financial reforms are considered to be represented in the form of inflation, national savings, schedule banks deposits, schedule banks lending and interest rate spread. After financial reforms the banking sector of Pakistan witnessed highly positive financial results. Though banks maintained upward trend in profitability, following factors created challenges for SBP: changing ownership structure, transformation in banking system composition, growing market competition, technological advancement and enhanced focus on corporate governance culture. According to Husain banking system plays an important role in financial sector and accounts for $95 \%$ of this sector and demonstrated a positive relationship with economic growth of Pakistan. The above ascertainment is the basis of this study i.e. exploring impact of financial reforms on economic growth of Pakistan. The study will be useful in understanding impact of reforms in financial sector on economic development of Pakistan and will also be useful for financial analysts to check overall banking role in promoting domestic and foreign saving and investment [11].

Following are the objectives of the study:

- Enlist the major Financial Reforms under taken by the Government of Pakistan in different regimes,

- Explore impact of financial reforms on economic growth of Pakistan, and

- Explore relationship among economic growth, deposits, lending, real interest rate, savings, and inflation.

Second chapter is about the literature review. Third and fourth chapters explain methodology and results. Fifth and sixth chapters enumerate conclusions and recommendations, respectively.

\section{LiterATURE REVIEW}

Trestle and Detragiache (2008) demonstrated a positive impact of the banking reforms on economic growth, especially in those countries where institutional environment was conducive [16]. Khan, Qayyum and Ahmad (2005) examined structural constancy of financial intensification in the presence of financial sector reforms 
which were integral part of liberalization process of economy. They demonstrated that financial debt and real interest have a positive impact on economic growth in long run. They ascertained, on the basis of their findings, that financial development has a vital and positive impact on the economic growth of a country [6].

Saez (2001) studied financial reforms in India and China. These countries were selected due to their similar development patterns. He argued that after banking sector reforms India was able to overcome the problems of bad debts by allowing new entrant in the market. While China tried to restore its state owned banks by way of asset management institutions [14].

Galbis examined financial sector reforms in eight developing countries, where financial sector reforms were implemented along with other structural reforms. The aim of these reforms was to improve monetary control and provide healthy and sound financial system. He recommended that all countries should continue with policies to improve monetary policy and should strengthen prudential regulation and supervision, privatize and restructure the financial institutions [8].

Research on the macro level efficiency of the banks has gained some attentions, but most of the researchers preferred European region, hence ignoring the south Asian region [4]. However, Shafique (2007) analyzed impact of banking sector reforms on economic growth of Pakistan and explored positive relationship between banking reforms and economic growth.

Gurley and Shaw found that financial reforms played very important role in the development process of any country [9], [10].

Roubini and Sala-i-Martin (1992) empirically analyzed the relationship between financial suppression and economic growth using panel data of 53 countries. They found that higher the financial suppression lower will be economic growth [13].

Researcher assess the financial systems of developing economies and found that if we compare the role of capital market and commercial banks, capital market played very small role whereas commercial banks have strong influence on financial system of developing economies. He further stated that banking sector have to face high reserve ratio and also ceilings on deposits and interest rates [7].

\section{FINANCIAL REFORMS IN PAKISTAN 1990-2000}

The overview of the financial reforms provided in this section with the help of the brief discussion of financial reforms by Zaidi (2008). The discussion is detailed below, which is segregated on the basis of various dimensions of the financial reforms [17]

\section{IV.PRIVATIZATION}

Privatization was introduced through a bill, and was amended to pave the way for privatization of the nationalized commercial banks (NCBs). Accordingly, shares of $\mathrm{MCB}$ and $\mathrm{ABL}$ were sold to private investors in the market. Initially $27 \%$ shares of the MCB were sold to private investors in April, 1991; however, another 49\% of their shares were sold in two consecutive steps in February, 1992 and January, 1993, respectively. In compliance of the act, the same proportion of $26 \%$ and additional $25 \%$ shares of ABL were sold to the private investors, in September, 91 and August, 1993, respectively [15].

\section{INFRASTRUCTURE/EFFICIENCY IMPROVEMENTS}

The act empowered the State Bank of Pakistan to have supervisory control over the investment banks including National Banking and Financial Institutions (NBFIs). The government accordingly delegated the powers to the SBP and increased the latter's supervisory jurisdiction to control the financial institutions. In this regards, SBP instructed all the financial institutions to get the approval of their credit ratings by the State Bank of Pakistan, this was effective from April, 1995. This policy was implemented in its letter for the commercial banks in June, 2000, which increased their efficiencies and improved their performance.

\section{BAD LOANS/NON PERFORMING LOANS (NPL)}

The reforms encouraged the regulatory body (SBP) to issue directives regarding the classification of the bad loans. The loans are to be classified as other assets are carried out. They were instructed to deal this classification as other assets especially mentioned (OAEM), substandard, doubtful or loss, depending on the payment due either in the form of the principal or their interests. The SBP after the classification of the NPLs, further instructed to provide the loans as per the proportion provided as provisioning against substandard, doubtful and loan categories were required to be made at the rate of $20 \%, 50 \%$ and $100 \%$ respectively.

\section{DEBT MANAGEMENT REFORMS}

In an endeavor to improve the debt management system in the banks, SBP established an independent department to deal with the securities. This system would help the banks in launching the auction system of public debt. They also facilitated in developing secondary market for the government owned securities. Another department named as Foreign Exchange Dealing Room (FEDR) was established in SBP in July, 1998. However, later on in February, 2000 these two departments were merged together to form Exchange and Debt Management Department (EDMD).

\section{MONETARy ManaGEMENT MEASURES}

State Bank of Pakistan instructed all the banks to maintain an average of $5 \%$ of its total demand liabilities with the state bank of Pakistan w.e.f. July, 1997. This had to be carried out at weekly basis. This helped the SBP to ensure the complete following-up of their instruction issued to the banks from time to time.

\section{EXCHANGE AND PAYMENT REFORMS}

Another company with the name of Central Depository Company of Pakistan Limited (CDCPL) was established in 1999. The company worked in collaboration with the IFC, 
Citibank, and other leading commercial banks and DFIs operational in the country (Pakistan). The company would have to facilitate the transfer of the stocks electronically. Securities and Exchange Company of Pakistan was established in 1999 through an act of Parliament called SECP Act, 1997, which was in replacement of the Corporate Law Authority. Now SECP deals in all kind of companies' registration and regulations, and working as regulatory body for corporate businesses throughout the country.

\section{THEORETICAL FrAMEWORK}

Deposits are the sum of money that the people lend to banks for the purpose of earning interest. Banks are totally depending on deposits, almost whole banking function is with deposits, without deposits banks will not able to lend or invest anywhere. Current deposits, call deposits, saving deposits, fixed deposits are different kinds of deposits. The amount bank gives as loan and releasing in other forms to its clients is called lending.

While looking at both savings and consumption behavior it was also observed that consumption is increasing more rapidly than savings so when there is more consumption it will lead to relatively low savings and vice versa. The lowest financial savings rate is attributable to a number of factors including increased uncertainty due to prolonged political transition and sharp deterioration of the macroeconomic environment. Specifically, visible slowdown in economic growth and strong inflationary pressures in the economy contributed to low financial savings.

It has been explored by various economists that high rate of inflation have unfavorable consequences for economic growth. Barro (1995) argued that inflation has a negative impact on economic growth. He also explored a negative relationship of inflation with deposits, lending, and savings. Inflation results in increase prices of commodities which leads diminished savings and decreasing the deposits. Low deposits lead to less lending and that results in less investments and hence leads to slow economic growth.

Following is the mathematical representation of the model estimated in this study:

$$
\begin{aligned}
& Y_{t}=\alpha_{o}+\alpha_{1} \ln (I N F)_{t}+\alpha_{2} \ln (N S)_{t}+ \\
& \alpha_{3} \ln (D E)_{t}+\alpha_{4} \ln (L E N)_{t}+\alpha_{5} \ln (R)_{t}+\varepsilon_{t}
\end{aligned}
$$

where, Y, INF, NS, DE, LEN, R and u represent gross domestic product (GDP), inflation, national savings, banks deposits, banks lending, real interest rate and error term, respectively.

\section{Methodology}

Secondary data was collected from annual reports and statistical hand book of central bank, and economic survey of Pakistan, for the variables for a period of $1973-2008$ ( $N=36$, for each variable). Ordinary Least Square (OLS by Carl Friedrich Gauss) is used to estimate the model, because under certain assumptions namely, the equation to be estimated; is linear in parameters, is non stochastic, has zero mean value, possesses equal variance of distribution etc. it becomes a powerful method of regression analysis. $\log (\mathrm{LN})$ of deposits, lending, and savings was taken and regression analysis was applied.

\section{Estimation AND Results}

Table-1 shows the results of Unit Root, Dickey-Fuller (DF) and Augmented Dickey-Fully tests, which were applied for the stationary of data.

According to results of regression analysis as provide in Table-2, inflation, interest rate, lending, saving and deposits explain $88.5 \%$ variation in the economic growth (i.e. $\mathrm{R}^{2}=$

\begin{tabular}{|c|c|c|c|c|c|c|}
\hline \multirow[b]{2}{*}{ Variables } & \multicolumn{3}{|c|}{ Level } & \multicolumn{3}{|c|}{$1^{\text {st }}$ Difference } \\
\hline & Lags & Intercept & Trend \& Intercepts & Lags & Intercept & Trend \& Intercept \\
\hline $\mathbf{Y}$ & 0 & $-4.66979 * \quad(-2.02)$ & $-6.391465^{*}(-3.5670)$ & 1 & $-7.178729 *(-2.9705)$ & $-7.027458 *(-3.5796)$ \\
\hline INF & 0 & $-0.368259 * \quad(-2.95)$ & $-3.638398^{*}(-3.5614)$ & 1 & $-8.43125 *(-2.28348)$ & $-5.200621 *(-3.5731)$ \\
\hline $\mathbf{R}$ & 0 & $-3.974499^{*}(-2.07)$ & $1.114639 * \quad(3.5614)$ & 1 & $-3.817422 *(-2.9665)$ & $-4.089002 *(-3.5731)$ \\
\hline LEN & 0 & $-2.812309^{*}(-2.95)$ & $-2.949084^{*}(-3.5614)$ & 1 & $-4.277648 \quad(-1.9871)$ & $-3.745340 *(-3.5731)$ \\
\hline NS & 0 & $-10.11490 *(-2.96)$ & $-9.926192 *(-3.5670)$ & 1 & $-5.98349 *(-2.00403)$ & $-4.432884 *(-3.5796)$ \\
\hline DE & 0 & $-4.254405^{*}(-2.96)$ & $-5.511926^{*}(-3.5670)$ & 1 & $-3.43208 *(-2.07024)$ & $-5.930496 *(-3.5796)$ \\
\hline
\end{tabular}
0.885).

TABLE 2. Estimation OF MODEL USING OLS (SAMPLE 1973-2008) (DEPENDENT VARIABLE GDP GROWTH)

\begin{tabular}{|l|c|r|r|l|l|l|}
\hline Variables & Coefficient & \multicolumn{1}{|l|}{ t-Statistic } & \multicolumn{1}{l|}{ Prob. } & $\mathbf{R}^{2}$ & DW & Prob. (F-statistic) \\
\hline C & $-0.5626^{*}$ & -2.1230 & 0.0431 & 0.885 & 2.2523 & 2.7274 \\
\hline INF & $-1.7868 *$ & -2.7594 & 0.0195 & & & \\
\hline NS & $3.3881^{*}$ & 2.1028 & 0.0443 & & & \\
\hline DE & $4.0068^{*}$ & 2.5115 & 0.0178 & & & \\
\hline LEN & 0.4636 & 1.2535 & 0.2582 & & & \\
\hline $\mathbf{R}$ & $-2.9019 *$ & -2.8101 & 0.0073 & & & \\
\hline
\end{tabular}


TABLE 3. CORRELATIONS MATRIX

\begin{tabular}{|l|l|l|l|l|l|l|}
\hline & GDP & Deposits & Lending & Interest Rate & Savings & Inflation \\
\hline GDP & 1 & $.898(* *)$ & $.907(* *)$ & $-.583(* *)$ & $.899(* *)$ & $-.428(* *)$ \\
\hline &. & .000 & .000 & .000 & .000 & .009 \\
\hline Deposits & $.898(* *)$ & 1 & $.999(* *)$ & $-.554(* *)$ & $.979(* *)$ & $-.495(* *)$ \\
\hline & .000 &. & .000 & .000 & .000 & .003 \\
\hline Lending & $.907(* *)$ & $.999(* *)$ & 1 & $.545(* *)$ & $.977(* *)$ & $-.492(* *)$ \\
\hline & .000 & .000 &. & .001 & .000 & .002 \\
\hline Interest Rate & $-.583(* *)$ & $-.554(* *)$ & $.545(* *)$ & 1 & $.494(* *)$ & .084 \\
\hline & .000 & .000 & .001 &. & .002 & .626 \\
\hline Savings & $.899(* *)$ & $.979(* *)$ & $.977(* *)$ & $.494(* *)$ & 1 & $-.552(* *)$ \\
\hline & .000 & .000 & .000 & .002 &. & .000 \\
\hline Inflation & $-.428(* *)$ & $-.495(* *)$ & $-.492(* *)$ & .084 & $-.552(* *)$ & 1 \\
\hline & .009 & .003 & .002 & .626 & .000 &. \\
\hline & & & & & \\
\hline
\end{tabular}

Inflation affects economic growth adversely .i.e. a unit increase in inflation decreases GDP by 1.78681 units (i.e. $\beta_{1}$ $=-1.7868, \mathrm{p}=0.0195)$. Interest rate has a significant negative impact on economic growth $\left(\beta_{5}=-2.9019, \mathrm{p}=\right.$ 0.0073). All variables have significant impact (i.e. at significance level of 5\%) on economic growth except lending. If inflation goes up the lender will also increase interest rate to save the time value of money. There is very strong positive relationship between economic growth with deposits, lending, interest rate spread and savings. Inflation and interest rates and are correlated to each other but the results are not significant in this study $(\mathrm{r}=0.084, \mathrm{p}=0.626)$

National savings and deposits have positive and significant impact on the economic growth, as 1 unit increase in NS and DE will increase GDP by 3.3881 and 4.0068 units, respectively (i.e. $\beta_{2}=3.3881, p=0.0443 \& \beta_{3}$ $=4.0068, p=0.0178$ ). Economic growth is significantly affected in a positive way by an increase in deposits, lending and savings by lowering the interest rate on lending and by increasing interest on deposits.

According to the correlation matrix provided in Table-3, all the variables are significantly correlated with each other (i.e. at $1 \%$ level of significance) correlation between inflation and interest rates which has $p=0626$. All the variables are positively correlated with economic growth with the exception of inflation and interest rate. They both have negative relationship with economic growth (i.e. $r=$ $.428, \mathrm{p}=0.009$ and $\mathrm{r}=-.583, \mathrm{p}=0.000$, respectively).

Results showed that economic growth and all the independent variables except inflation and real interest rate are significantly associated. Due to inflation the prices of commodities increases and that results in reduction in savings. Where there is reduction in savings it leads to reduce in the level of investment and that adversely affects economic growth.

\section{CONCLUSION \& RECOMMENDATIONS}

Before the 1990's public sector banks dominated the financial sector. At that time, one of the reasons behind slow economic growth was interest rate ceiling, requirement of high reserves and restrictions in the credit allocation. But after the reforms the structure of banking system has changed tremendously. Local private banks were in operation and government privatized the nationalized banks. Results showed positive relationship between economic growth with deposits, lending and savings, and negative relationship with inflation and interest rate. Better performing banking sector is now helping Pakistan to achieve higher growth rates.

Financial reforms have a significant impact on the banking sector and economic growth. Also reforms change the bureaucratic culture of the banks. Reforms overcome the problems of overstaffing and poor customer service. Inflation significantly affects the economic development. The mechanism for the economic growth from the financial sector is; less inflation leads to more savings and high interest rate on deposits will leads to more lending, higher the lending will results in more investment and more investment leads to more economic growth.

For slow economic growth interest rate ceiling was one of the major factors, so interest rate ceiling should be removed permanently as empirically demonstrated in this study. For balanced credit ratios between the government and private sector, interest rate must be market oriented.

There should be suitable interest rates to generate deposits which can be easily utilized to fulfill the requirement of investments and therefore people have the opportunity to deposit their money with the banks instead of investing anywhere else. Government should take concrete measures to control the inflation for the betterment of economic development, by using monetary policy. The central bank should decrease money supply to decrease inflation.

\section{REFERENCES}

[1] Akhtar, S. Pakistan Banking Sector Reforms: Performance and Challenges, Geneva, 2007.

[2] Ang, B. J. and McKibbin, J.W. Financial Liberalisation, Financial Sector Development and Growth: Evidence from Malaysia, Brookings Discussion Papers, 2005.

[3] Bonaccorsi, P. E. and Hardy, C. The Effects of Banking System Reforms in Pakistan, IMF Working Paper No. 01/138, Washington DC, 2003.

[4] Brown, K. and Skully, M. International studies on comparative banking: A survey of Recent Developments, SSRN Working Paper No. 365920, 2003.

[5] Farooq, A. M. Behaviour of Interest Rates - Post Liberalization, State Bank of Pakistan, 1995.

[6] Farooq, S. U., Afridi, S. A. and Alam, W. Banking Reforms in Pakistan - Impact and Implications, international Bulletin of Business Administration, (7) pp. 55-60, 2010.

[7] Fry, M.J. Money, Interest and Banking in Economic Development (second edition), Baltimore, John Hopkins UP, 1995.

[8] Galbis, V. Financial Sector Reforms in Eight Countries: Issues and Results IMF Working Paper No. 95/141, 1995. 
[9] Gurley, J.G. and Shaw, E.S. "Money in a Theory of finance." Washington D.C. Brookings Institution, 1960.

[10]Gurley, J.G. and Shaw, E.S. "Financial Structure and Economic Development." Economic Development and Cultural Change, 1967.

[11]Husain, I. Financial Sector Reforms in Pakistan, Paper read at ItalyPakistan Trade and Investment Conference, Rome on September 28, 2004.

[12] Peterson, B. S. Financial reform in a devolved African country: lessons from Ethiopia Public Administration and Development Volume 21, Issue 2, pp. 131-148, 2001.

[13] Roubini, N. and X. Sala-i-Martin. "Financial Repression and Economic Growth." Journal of Development Economics, 39:5-30, North Holland, 1992.

[14] Sáez, L. Banking reform in India and China International Journal of Finance \& Economics Volume 6, Issue 3, Date: July 2001, pp. 235-244, 2001.

[15] Shafiq, M. The Banking Sector - A Comparative Study of Affects of Recent Reforms in Pakistan Greenwich School of Management, 2007.

[16] Tressel, T and Detragiache, E. Do Financial Sector Reforms Lead to Financial Development? Evidence from a New Dataset IMF Working Paper No. 08/265 International Monetary Fund (IMF) - Research
Department and International Monetary Fund (IMF) - Research Department, 2008.

[17]Zaidi, A. Issues in Pakistan Economy, $6^{\text {th }}$ ed., Oxford University press, 2008

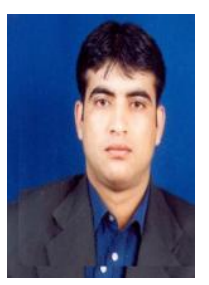

Rehman, W, born on 3rd January, 2011 in Pakistan. Pursuing M. Phil Leading to $\mathrm{PhD}$ studies in the Department of Management Sciences, Foundation University, and Islamabad, Pakistan. (PRINCIPAL AUTHOR)

He worked in the Higher Education Commission, as Research Associate, Project Manager during the period 2003 to 2010. Currently pursuing doctoral studies from Foundation University, Islamabad. A research article titled, "Downsizing and Its after affects lead to Poor Performance of the Emaployees: A conceptual Model" has been accepted for publication in the African Journal of Business Management. His research area is Human Resource Management.

Mr. Rehman has recently attended a research conference in Hong Kong during 2-3 July, 2011 